DOI 10.14746/ssp.2020.1.9

\author{
Anna SAKSON-BOULET \\ Adam Mickiewicz University in Poznań \\ ORCID: 0000-0002-4014-7483
}

\title{
The Clean Air Priority Programme - Evaluation and Perspectives
}

\begin{abstract}
The article aims to evaluate the effectiveness of the Clean Air Priority Programme and to establish possible threats to its success. The National Fund for Environmental Protection and Water Management's programme constitutes an important element of the government programme that goes by the same name. This study, with the aid of an institutional-legal, decision-making and quantitative analysis will undertake to answer the following research questions: (1) can the realisation of the aim formulated in this programme result in an improvement of air quality in Poland?; (2) what, if any, barriers stand in the way of achieving the programme's aims?; (3) does the Clean Air Programme require further changes? On account of the high energy consumption of Polish homes, which typically results in their owners heating them with the cheapest fuels, emitting significant amounts of pollution, should the programme aims be assessed positively? In the process of discussions however, three types of barriers have come to light: (1) those related to the effective distribution of funds, (2) difficulties arising from programme frameworks that potential beneficiaries might encounter, and (3) potential limitations in the access to EU funding. On account of threats to the success of the programme that have been identified, it is expected that further changes to its functioning will be introduced as well as the ring-fencing of funds for thermo-modernisation and change of heating systems.
\end{abstract}

Key words: air quality, smog, clean air policy, Clean Air Programme, Poland

\section{Introduction}

I n January 2017, the Polish government led by Beata Szydło deliberated on the recommendations of the Government Committee for the Economy in respect of undertaking the necessary action to combat the high concentrations of air pollution occurring across significant parts of Poland. Thus, fifteen areas of action were determined in respect to creating the national Clean Air Programme, a central element of which is the "prioritisation of funding for The National Fund for Environmental Protection and Water Management (NFEP\&WM) for the purposes of 
conducting a swift improvement in air quality so as to gain the maximum benefit for people's health and ecology for every Polish Złoty of funds spent" (Rekomendacje, 2017). As a consequence, the Clean Air Programme realised by The National Fund for Environmental Protection and Water Management was established. Prime Minister Mateusz Morawiecki in his exposé of 12 December, 2017 recognised the policy for an improvement in air quality as one of the priorities of his government, emphasising that "clean air is a challenge for all mankind - a measure of whether Poland is indeed a mature country," and further "we realise that not all of us can afford clean fuels. The programme to combat smog therefore is one that supports the poorest, who cannot afford today to pay for insulation, new windows or doors, nor indeed good fuel that doesn't poison the atmosphere" (Exposé, 2017).

On 19 September 2018, the first applications were accepted for the Clean Air Priority Programme - in the main based on funding the exchange of inefficient sources of heating in favour of solid fuels and thermo-modernisation of homes. The beneficiaries are the homeowners, or those with ownership rights to a flat with a separate mortgage deed. Moreover, those who have begun building their house, as well as buildings that have not thus far been registered for use also qualify.

In Poland, so far, there has never been a planned programme for the improvement of air quality with such a large budget. It has been planned that the programme, which ends on 30 September 2029 (the contract for funding is for the period ending 31 December 2027) will cost PLN 103 billion. Beneficiaries will receive a total of PLN 63.3 billion in grants and loans amounting to PLN 39.7 billion. In this context, the maximum value of qualified costs of funding for investors is calculated to be PLN 53,000. For a loan, the value of maximum costs for the individual, such as main doors, amounts to PLN 2,000 per $\mathrm{m}^{2}$. The relative intensity of funding depends on average monthly earnings per capita in a household, as well as whether a person is eligible for thermo-modernisation as tax relief (if such funding is available, it is to a lesser degree) and is in the vicinity of 15 to $90 \%$ of the qualified cost of investment. The highest available funding is for families that have an income of less than PLN 600 per month, per person (Program Priorytetowy Czyste, 2019, pp. 2-3 and 8-10).

Thus far, ${ }^{1}$ two modifications to the programme have been introduced. The first was primarily related to changes in tax law. On 1 January 2019,

1 This brief study was completed on 1 September 2019. 
the Act amending the Personal Income Tax Act and the Act on Flat-Rate Income Tax on certain personal income of individuals of 9 November 2018 entered into force. This act introduced the rebate on thermo-modernisation - allowing for a tax deduction in the form of expenses related to the insulation of a home, and the waiving of tax for grants received in respect to the Clean Air Programme (Ustawa o, 2018). As a consequence of the need to adapt the IT system to this tax relief, the intake of applications was suspended between 1 and 21 of January (Nabór, 2019). The second modification, discussed more broadly in the subsequent part of this study, was introduced on 29 July - its key element being the integration of municipal local government participation in the process of initiating the programme, allowing for the intake of applications and their subsequent verification (Ogłoszenie, 2019).

The National Fund for Environmental Protection and Water Management, together with Regional Funds for Environmental Protection and Water Management, and, starting from the end of July 2019, also municipal administrations, have been responsible for the realisation of the above mentioned programme. Thus, collaboration between the respective Funds commenced on 7 June 2018, when an agreement was signed on the realisation of the programme using Regional Funds for Environmental Protection and Water Management (Narodowy Fundusz Ochrony Środowiska i Gospodarki Wodnej, 2019a, p. 25). These funds, according to the provisions of the Environmental Protection Law Act (Ustawa Prawo, 2001, Art. 386 and 400a) belong to the institutions which handle environmental protection. These in turn make these means available to local governments, the private sector, public institutions, NGOs and individuals, in the form of low interest loans, grants or funding for bank loans (Leksykon, 2009 , p. 33). The National Fund finances activity from income, among others from fees and penalties in respect to ecology, as well as fees for exploitation and licenses. It is also responsible for overseas subsidies designated for the protection of the environment in Poland, including European funds under the Cohesion Fund or European Regional Development Fund (Narodowy Fundusz Ochrony Środowiska i Gospodarki Wodnej, 2014, p. 17).

Up to 2015, The National Fund and Regional Funds conducted two collaborative priority programmes tied to the improvement of air quality - Kawka and Prosument. Funds made available for the period 2013-2015 amounted to PLN 274.1 million and 150.1 million respectively, out of which only PLN 63.3 million and 12.7 million respectively went unused 
(Narodowy Fundusz Ochrony Środowiska i Gospodarki Wodnej, 2016a, p. 9). The first of these was concerned with, among others, replacing people's high-emission boilers, or fireplaces with centralised solid fuel networks or low-emission systems of heating, elaboration of heating networks and the installation of solar collectors. The above mentioned actions, serving the limitation of low-emission heating, were open to organisations, individuals, companies and corporations (Program Priorytetowy Likwidacja, p. 4). In the framework of the Prosument programme there were plans for an increase of energy production from renewable sources by individuals and corporations through the installation of small, renewable energy systems for the production of electricity or central heating. In this context, there was financial support for, among others, the purchase of heating pumps and solar collectors (Program Priorytetowy Prosument, p. 5).

The realisation of the Kawka programme was envisaged for 2018 (Program Priorytetowy Likwidacja, p. 2), the Prosument programme for 2019 (Program Priorytetowy Prosument, p. 2). Towards the end of 2015, there were plans for initiating the Rys programme for the thermomodernisation of houses and buildings, with a budget of PLN 400 million. Among prospective beneficiaries of this were to be individuals, local government offices and NGOs. This programme was to end by 2023 (Program Priorytetowy Poprawa, pp. 1-2, 6).

After Law and Justice came to power in 2015, The National Fund received new management ${ }^{2}$ (in November 2015 part of the Supervisory Board was changed and in December, the Board itself), which conducted a review of the environmental programmes hitherto realised (Narodowy Fundusz Ochrony Środowiska i Gospodarki Wodnej, 2016b, pp. 3-4). In 2016, "[o]n account of the overlap of areas of support in the programmes Kawka, Ryś and Prosument as well as the labour intensive-

${ }^{2}$ The organs of the National Fund are the Supervisory Board and Board. The Environmental Protection Law Act states that the composition of the former, which can include a maximum of twelve members, is determined by the minister relevant for environmental affairs, who elects and dismisses it. The board, apart from dealing with environmental affairs, has delegates from ministries to do with public finances, energy and regional development. The National Fund Board is composed of three to five members. On the recommendation of the Supervisory Board the relevant minister appoints and dismisses the Board Director and their deputies, appointed from those who took part in an open recruitment procedure for these positions. The relevant organs of the National Fund are governed by the Environmental Protection Law Act, Art. 400c-400d, 400h-400i, 400k and 400o. 
ness of administration and, at the same time, lack of adaptation to the real needs and conditions set by regions, The National Fund decided upon a new, unified and flexible mechanism of support" (Nowy). The three priority programmes mentioned above were therefore replaced by the single largest programme in the history of the NFEP\&WM, known as Clean Air.

This study aims, therefore, to assess the effectiveness of this programme and to define potential threats to its success. The following research questions were therefore set: (1) can the realisation of the aim formulated in this programme result in an improvement of air quality in Poland?; (2) what, if any, barriers stand in the way of achieving the programme's aims?; (3) does the Clean Air Programme require further changes? The answers to these questions were undertaken by means of quantitative analysis, decision theory and institutional-legal analysis.

\section{Aims and plans of the Clean Air Programme}

At the end of 2016 in Poland, close to 5.4 million homes, of which about $70 \%$ were in rural areas, were estimated not to be connected to a gas or heating network. Solid fuels are used to heat 4.5 million buildings (over $80 \%$ of all homes). Coal-fired boilers, ten or more years old, are found in 1.7 million of these, the majority being low-efficiency boiler hoppers. It is possible to burn silts and flotation concentrates as well as waste $^{3}$ in such boilers, which emits the most pollution. Approximately one million buildings are heated mainly by biomass, including wood, and 50,000 buildings - by means of coal-fired stoves (Pytliński, 2018, pp. 34-35).

Over half of homes in Poland were built between 1945 and 1989, and nearly a quarter of them before WWII, which translates into very low

3 Silts and flotation concentrates are bi-products of the production of stone coal, resulting from the separation of pollutants from the extracted coal. In consequence, a water suspension of rock and coal particles with a diameter of 1-3 mm arises. In the process of flotation, the coal particles are separated from the stone, producing a flotation concentrate. From the remnants of flotation, after partial water evaporation, coal silt is produced. Definition according to: Co to sa muly i flotokoncentraty węglowe, Poznań City Portal, http:/www.poznan.pl/mim/main/-,p,43191,43199. html, 6.08.2019. 
energy efficiency, related to the poor quality of construction and use of the cheapest materials (Zaborowski, 2014, p. 92). Moreover, over $70 \%$ of buildings in Poland do not have any thermal insulation of internal walls or have been poorly insulated (Pytliński, 2014, p. 9). Importantly, insulated buildings use from $30 \%$ up to as much as 50\% less energy (Wantuch, 2016). Combining a higher degree of insulation of construction walls with modern automated central heating systems can lead to as much as a $60-70 \%$ decrease in energy consumption (Walczak, Zaborowski, 2018, p. 20).

Given the mass heating of homes by means of solid fuels and the widespread lack of external wall insulation or installation of an insufficient insulation layer (less than $10 \mathrm{~cm}$ ), which leads to a greater demand for heating, one can argue that homes constitute the main source of low-level air pollution, understood as emissions from emitters below 40 metres altitude (Jakość, 2018, p. 1). The extent of low-level emissions and nature of pollutants depends on the quality and quantity of fuel burnt, the technical state of heating appliances and construction density. Typical compounds emitted during the burning of solid fuels for heating purposes are particulate matter, carbon monoxide, sulphur oxides, nitrogen oxides and organic compounds (Mazurek, 2018, p. 71).

In Poland, a considerable challenge involves the maintenance of normative concentrations of particulate matter in the air. As a result of EU air quality norms relating to particulate matter $\mathrm{PM}_{10}$ (fractions with a diameter of particles up to $10 \mu \mathrm{m}$ ), having been exceeded for the past many years, the EU Court of Justice in Luxembourg, in its judgement of 22 February 2018, found Poland guilty of breaking EU law. The judges concluded that, at least from 2007 to 2013, Poland systemically failed to comply with the acceptable average daily (in 35 out of 46 assessment zones) and average annual (in 9 zones) values of $\mathrm{PM}_{10}$ concentrations, and had not undertaken the necessary steps to ensure a change in this respect. Moreover, the Court also found that excess levels were noted until the end of 2015 (Judgment of the Court of Justice of the European Union, 22 February 2018, ECLI:EU:C:2018:94).

The National Centre for Emissions Management data obtained from government air quality monitoring confirm the overwhelming share of homes in the emission of particulates harmful to people's health. ${ }^{4}$ In 2017,

${ }^{4}$ Particulate matter leads to the development and exacerbation of respiratory diseases such as asthma and lung cancer. Particulates with a diameter less than $2.5 \mu \mathrm{m}$, penetrating into the bloodstream through the walls of the alveoli, cause heart arrhyth- 
about $47 \%$ of $\mathrm{PM}_{2.5}$ emissions (particulate fractions with a diameter not exceeding $2.5 \mu \mathrm{m}$ ) resulted from fuel burning outside industry, out of which $80 \%$ were related to hard coal and wood burning in homes (Instytut Ochrony Środowiska - Państwowy Instytut Badawczy, Krajowy Ośrodek Bilansowania i Zarządzania Emisjami, 2019, p. 13). Krajowy program ochrony powietrza do roku 2020 (z perspektywa do roku 2030) [The National Programme of Air Protection by 2020 (with a perspective by 2030] indicated the main sources of exceeding acceptable levels of $\mathrm{PM}_{10}$ in Poland. The largest proportion of such emissions, over $88 \%$, come from the heating of buildings by individuals (Ministerstwo Środowiska, Departament Ochrony Powietrza, 2015, p. 21).

Particulate matter (PM) is a mixture of fine solid particles and droplets of liquid suspended in the air which are primary pollutants emitted directly into the atmosphere, as well as secondary pollutants generated in the atmosphere as a result of chemical reactions. Primary PM comes from natural sources, such as volcanic eruptions, as well as from anthropogenic sources related mainly to fuel combustion processes, especially those of solid fuels, and industrial processes (for more on PM see: Sakson-Boulet, 2018).

Bearing in mind the above data, the aims set out in the Clean Air Programme ought to be seen in a positive light, in terms of:

1) an improvement in energy efficiency of existing homes;

2) a lowering of particulate matter emissions and other pollutants into the atmosphere from existing homes;

3 ) an avoidance of air pollutants from newly constructed buildings (Program Priorytetowy Czyste, 2019, p. 1).

The above aims are strictly connected to one another. Greater energetic efficiency following from lower energy consumption, thereby results in a lower emission of harmful particles into the atmosphere. The achievement of the above mentioned aims was translated into the specific outcomes presented in Table 1.

mia, ischaemic cardiovascular diseases and high blood pressure. In cases of heart failure a stroke or even death may ensue. Fine particulate matter also has a deletirious effect on the central nervous system (headaches, anxiety ADHD, concentration loss, dementia and cognitive dysfunction). For more on the effects of particulate matter on people's health see: J. Jędrak, E. Konduracka (2017), Wptyw zanieczyszczeń powietrza na zdrowie, Krakowski Alarm Smogowy, Kraków as well as H. Mazurek, A. Badyda (eds.) (2018), Smog. Konsekwencje zdrowotne zanieczyszczeń powietrza, PZWL Wydawnictwo Lekarskie, Warszawa. 
Indicator Value for attaining the Clean Air Programme aims

\begin{tabular}{|c|c|c|}
\hline Indicator & $\begin{array}{c}\text { Planned value of indica- } \\
\text { tor after programme } \\
\text { completion } \\
\text { (programme version as } \\
\text { of } 19 \text { Sept. 2018) }\end{array}$ & $\begin{array}{c}\text { Planned value of indica- } \\
\text { tor after programme } \\
\text { completion } \\
\text { (programme version as } \\
\text { of } 29 \text { July 2019) }\end{array}$ \\
\hline $\begin{array}{l}\text { The number of apartment build- } \\
\text { ings with improved energy effec- } \\
\text { tiveness }\end{array}$ & $\begin{array}{l}\geq 4000000 \\
\text { buildings }\end{array}$ & $\begin{array}{l}\geq 3050000 \\
\text { Buildings }\end{array}$ \\
\hline $\begin{array}{l}\text { The number of old-generation } \\
\text { boilers replaced in relation to } \\
\text { low-emission ones in existing } \\
\text { buildings }\end{array}$ & $\begin{array}{c}\geq 3000000 \\
\text { buildings }\end{array}$ & $\begin{array}{l}\geq 3000000 \\
\text { Buildings }\end{array}$ \\
\hline $\begin{array}{l}\text { The number of low-emission } \\
\text { sources of heating installed in re- } \\
\text { cently built buildings }\end{array}$ & $\begin{array}{l}\geq 1000000 \\
\text { buildings }\end{array}$ & $\begin{array}{l}\geq 50000 \\
\text { buildings }\end{array}$ \\
\hline End-energy exploitation limit & $\begin{array}{c}\geq 21800000 \mathrm{MWh} / \text { per } \\
\text { year }\end{array}$ & $\begin{array}{c}\geq 21800000 \mathrm{MWh} / \text { per } \\
\text { year }\end{array}$ \\
\hline $\begin{array}{l}\text { Sulphur dioxide emission limit } \\
\left(\mathrm{SO}_{2}\right)\end{array}$ & $\geq 270000 \mathrm{Mg} /$ per year & $\geq 270000 \mathrm{Mg} /$ per year \\
\hline $\begin{array}{l}\text { Particulate matter emission aver- } \\
\text { age under } 10 \mu \mathrm{m}\left(\mathrm{PM}_{10}\right)\end{array}$ & $\geq 68400 \mathrm{Mg} /$ per year & $\geq 68400 \mathrm{Mg} /$ per year \\
\hline $\begin{array}{l}\text { Particulate matter emission aver- } \\
\text { age under } 2.5 \mu \mathrm{m}\left(\mathrm{PM}_{2.5}\right)\end{array}$ & $\geq 61100 \mathrm{Mg} /$ per year & $\geq 61100 \mathrm{Mg} /$ per year \\
\hline Benzo- $\alpha$-pyrene emission limit & $\geq 87 \mathrm{Mg} /$ per year & $\geq 87 \mathrm{Mg} /$ per year \\
\hline $\begin{array}{l}\text { Carbon dioxide emission limit } \\
\left(\mathrm{CO}_{2}\right)\end{array}$ & $\begin{array}{c}\geq 302000000 \mathrm{Mg} / \text { per } \\
\text { year }\end{array}$ & $\begin{array}{c}\geq 30,2000,000 \mathrm{Mg} / \text { per } \\
\text { year }\end{array}$ \\
\hline $\begin{array}{l}\text { Nitrogen oxide emission limit } \\
\left(\mathrm{NO}_{\mathrm{x}}\right)\end{array}$ & $\geq 39500 \mathrm{Mg} /$ per year & $\geq 39,500 \mathrm{Mg} /$ per year \\
\hline $\begin{array}{l}\text { Additional production capacity } \\
\text { of electricity for installed photo- } \\
\text { voltaic cells }\end{array}$ & $\begin{array}{l}\text { Aim not taken into ac- } \\
\text { count in version } 1 \text { of the } \\
\text { programme }\end{array}$ & 3,000 Mwe \\
\hline
\end{tabular}

Source: Author's research based on Program Priorytetowy Czyste Powietrze, version in place as of 19 Sept. 2018, p. 1, http://www.wfosgw.poznan.pl/program-priorytetowyczyste-powietrze/program-priorytetowy-czyste-powietrze-wersja-obowiazujaca-do31-12-2018-r/, 12.08.2019 and version in place as of 29.07.2019, pp. 1-2, http://www. wfosgw.poznan.pl/program-priorytetowy-czyste-powietrze/program-priorytetowy-czystepowietrze-zasady-obowiazujace-od-29-07-2019-r/, 1.08.2019.

It is worth noting that two indicators in respect to the realisation of aims have changed:

1) the number of buildings with improved energy effectiveness. It was assumed that there would be at least 3.05 million buildings, instead 
of the initial 4 million, around 31\% less than in the first version of the programme;

2) the number of low-emission heating sources installed in newly constructed buildings. In the present version of the programme, at least 50,000 was assumed, some $2,000 \%$ less than in the initial version.

One can therefore $\operatorname{argue}^{5}$ that the correction of the first indicator is related to the assumption that beneficiaries get two related improvements - the exchange of old-generation boilers and the insulation of buildings. The number of buildings with improved energy efficiency was approximated to the number of buildings where heating sources were to be replaced (respectively 3.05 and 3.0 million). This link is justified, for the replacement of a boiler (and as a result, heating fuel without thermo-modernisation) leads to an increase in solid fuel costs. The programme thus argued that thermo-modernisation on its own would only be possible in homes equipped with heating sources such as a local heat network, thermal pump, gas boiler, oil boiler, electrical heating appliances or solid fuel thermal sources that fulfil at a minimum, class 5 of EU norms 303-5:2012 6 and for which building permission was issued before 15 December 2002. The significance of this date is that the old norms relating to insulation of walls were applied in the building planning process (Program Priorytetowy Czyste, 2019, p. 8).

In the present version of the programme, financial support for the installation of low-emission heating sources has been decreased for owners of newly constructed buildings where, according to current binding principles, all expenses relating to investment have to be realised by the end of 2019. Grants and loans from 2020 on will apply

${ }^{5}$ Regional Environmental Protection Funds, in their announcements on changes in the Clean Air Programme do not point to a modification of indicators or explain their causes.

6 The European Committee for Standardisation introduced three classes of condensing boiler heaters: 3, 4 and 5 with the norm EN 303-5:2012. The boiler's thermal efficiency and maximum emission values of the following pollutants determines its given class: volatile organic compounds, particulate matter and carbon monoxide. For further discussion see: J. Pałasz (2016), Niska emisja ze spalania węgla i metody jej ograniczenia, Wydawnictwo Politechniki Śląskiej, Gliwice, p. 132. January 12020 , according to Commission Regulation (UE) 2015/1189 of 28 April 2015 implementing Directive 2009/125/EC of the European Parliament and of the Council with regard to ecodesign requirements for solid fuel boilers (OJ EU L 193/100, 21.07.2015), the norm presently in force will be broadened. 
only to the owners of already constructed buildings. This may be a consequence of the fact that, as of 1 January 2020, according to the Commission Regulation (EU) 2015/1189 of 28 April 2015 implementing Directive 2009/125/EC of the European Parliament and of the Council with regard to ecodesign requirements for solid fuel boilers (OJ EU L 193/100, 21.07.2015), new, greater and broadened norms will come into force for these heating appliances and systems - among others a ceiling will apply to the level of emissions of nitrogen oxide. As a result, only heating appliances and systems that fulfil new norms will be available for sale. It may well also be the case that this change is related to the World Bank experts' recommendations, who collaborated with the Polish government on the optimisation of financial instruments for homes in respect to limiting air pollution, questioning financial support in any form to owners of recently built homes ${ }^{7}$ (Bank, 2019). In this context, low-level emissions first and foremost come from old buildings poorly insulated and with old heating appliances and systems - not from those built at present.

The complete realisation of programme aims and the replacement of at least three million old-generation boilers with low-emission ones, the improvement of energy efficiency of over three million homes and, as a consequence, limiting emissions of $\mathrm{SO}_{2}, \mathrm{PM}_{10}, \mathrm{PM}_{2.5}$, benzo- $\alpha-$ pyrene and $\mathrm{CO}_{2}$, provides hope for a significant improvement in air quality and reducing low-level emissions. For example, in 2017, total emissions of $\mathrm{PM}_{10}$ resulting from burning fuels outside of industry (household emissions combined with small businesses, hospitals and schools heated by burning coal) amounted to $114,048.59 \mathrm{Mg}$, while the programme aims to reduce emissions of such pollutants by at least $68,400 \mathrm{Mg}$ annually. In turn, emissions of $\mathrm{PM}_{2.5}$ from burning processes for 2017 totalled $68,503.2 \mathrm{Mg}$, with an aim to reduce this to at least $61,100 \mathrm{Mg}$ annually (Instytut Ochrony Środowiska - Państwowy Instytut Badawczy, Krajowy Ośrodek Bilansowania i Zarządzania Emisjami, 2019, pp. 13 and 17). In order to eliminate practically all lowlevel emissions, it would be necessary to provide financial support for thermo-modernisation and the installation of low-emission sources of heating in apartment buildings, which the Clean Air Programme does not include.

7 The Polish government's cooperation with the World Bank is discussed in a further part of this article. 


\section{Barriers in the realisation of the government programme combatting low-level emissions}

Barriers to the realisation of the Clean Air Programme can be divided into three groups:

1) those related to the distribution of funds,

2) those for potential beneficiaries of the programme and its construction,

3) those resulting from potential limitation of access to grants from EU funding.

In the course of the first ten months, only the Regional Environmental Protection and Water Management Funds administered the programme. The tempo of processing applications, a consequence of the insufficient number of administrative staff, was highly inefficient. In 2018, from 19 September to the end of December, 25,519 applications were submitted for funding to the order of PLN 405 million in grants and close to PLN 144 million in loans. Only 59 contracts were signed (most in the Mazowieckie Region - 29, Pomorskie - 16, Warmińsko-Mazurskie - 9 and Lubuskie - 5), with grants amounting to PLN 636,000. No contracts were signed in twelve regions (Narodowy Fundusz Ochrony Środowiska i Gospodarki Wodnej, 2019, p. 27). From 21 January (when the programme in 2019 was renewed after introducing tax relief for thermo-modernisation) to 28 June 2019 , close to 38,500 applications were submitted and almost 26,000 contracts were signed (Minister, 2019).

From the above data, it can be seen that in 2019 the tempo of assessing applications increased, but continued to be insufficient in the context of achieving the programme aims. The realisation of the programme may last till 30 June 2029, meaning that, on average, around 281,000 houses ought to undergo thermo-modernisation and replacement of solid fuel boilers for heating each year. This aim will certainly not be attained in the first year, because the number of contracts signed from the beginning of the programme until 28 June 2019 (over nine months) totalled 26,000, whereas signing a contract does not equate to the implementation of its object, which can take up to 30 months from the date of the initial submission for funding.

The Minister for the Environment, Henryk Kowalczyk, during a press conference on 2 July 2019, did not express his concern with the lack of effectiveness in regard to the completion of tasks in the Regional Funds, stating: "The work at hand is in accord with the timetable - there is no Re- 
gional Environmental Protection and Water Management Fund that has exceeded the time for assessing a correctly submitted application, which is 90 working days" (Minister, 2019). A period of four calendar months was written into the programme regulations (Narodowy Fundusz Ochrony Środowiska i Gospodarki Wodnej, 2019b, p. 4), available on the portal for beneficiaries, but as the Regional Environmental Protection and Water Management Fund in Gdansk informs, the period indicated "is of an instructional nature and depends on the level of interest in the Programme and the number of applications submitted" (Najczęściej, n.d.). It should be noted that the period of 90 working days concerns the assessment, not the signing of the contract, which takes place after its confirmation by Regional Funds as a resolution of the board granting funding.

In this context, potential beneficiaries have posted negative comments on the Internet concerning the efficiency of customer service, for example: "An application submitted on 10 October 2018 [...] has unfortunately 'fallen into a black hole' after 11 months. In Lublin, in the office, telephone receivers were taken off the hooks and put on the table [...]. The programme does not work" (comment, 22.08.2019); or "I submitted an application on September 2018 and it has not even been assessed - Mazowsze" (comment, 12.08.2019). The above comments (over two hundred) followed an article on changes in the programme (Program, 2018). As the media reported, some applicants received a decision before the end of the ninety working days - but these were rejections, containing information on the need to re-submit documents because of mistakes made in the completed form (Wantuch, 2019a).

Despite the surprisingly positive assessment of the tempo of programme completion, during the aforementioned press conference of 2 July 2019 the Minister for the Environment forecast the transfer of fund distribution to local governments. No doubt that the threat of losing EU funding as a consequence of insufficient improvement in programme operations influenced the above decision, discussed in this brief study in relation to the financial barriers to its completion. Regional Funds began signing agreements to introduce the Clean Air Programme together with municipal local governments several days after Minister Kowalczyk's announcement, and around 400 were concluded by 31 July 2019 (Kowalczyk, 2019). Following the programme changes, after 29 July 2019 the acceptance and verification of applications became possible in municipal offices that had signed an agreement with a Regional Environmental Protection and Water Management Fund. Importantly, it is within the remit 
of municipal officials to maintain contact with applicants, who can then amend and add to their submissions, so as to avoid the subsequent assessment of applications containing mistakes.

The Ministry of the Environment estimates that by the end of 2019 over 100,000 applications will have been submitted, which makes the completion of programme aims questionable (Minister, 2019). Easier submission of applications by potential beneficiaries may improve the programme's functioning - provided that there are sufficient numbers of municipal officials to administer it. This is by no means certain, for, having been burdened with new tasks, municipal offices have not received additional funds for their completion. Secretary General Leszek Świętalski of the Association of Rural Municipalities has observed that "[ $t$ ]he requirements (arising from agreements with Regional Funds, such as ensuring computer work stations with access to the Internet) oblige municipalities to bear the burden of financial and human resources without compensation" (Nocun, 2019). This raises the question of the tempo of payments. According to the recommendations, among others of the Polish Smog Alert, commercial banks should also be parties to this venture (Apel, 2019).

Potential barriers to beneficiaries, apart from the above mentioned lack of broad access to the relevant institutions where enquiries can be made and applications submitted, arise from the difficulties in completing the applications without specialist help. The many signals concerning the highly complicated nature of the application forms led to changes in the instructions for its completion (at present over 50 pages), though many applicants still require help. The application has seven parts:

- investment completion period, applicant's details, and bank account number for transfer of funds;

- a detailed outline of the planned activity;

- outline of personal finances;

- summary of costs and means of financing the planned activity (on submission, the beneficiary's dashboard generates this automatically);

- declarations on the part of the beneficiary, for example in relation to avoidance of overlapping funding and fulfilment of technical requirements relating to heating systems;

- submission of relevant attachments (i.e., a document confirming income is obligatory);

- submission date and signature.

From the applicants' point of view, most difficulties concerned the second part of the application - the detailed outline of planned activities 
for investment (in the case of thermo-modernisation an energy audit of the apartment or building in question is useful) and technical details. The assessment of the costs of the planned work is also necessary when completing the application. Further, applications are set aside to be corrected due to mistakes made in the calculations of the annual income of all family members (part three).

In the face of the many uncertainties in the completion of applications, consulting firms have initiated comprehensive services such as conducting energy audits of buildings, completion of the application and relevant attachments, documentation for payment of funds, submission of application, legal assistance and consultation - all during the completion of the planned investment. Firms that offer assistance in gaining funds for the Clean Air Programme are active in all regions and their services can without any difficulty be found online. It is therefore possible to conclude that there is a lack of certified energy auditors in municipal offices who can provide advice free of charge in respect to improving the energy efficiency of a given building, as well as the fact that professional advice should be more widely available in the relevant local government offices.

One important barrier to the full realisation of the programme aims appears to be that it is not sufficiently attractive. It would be better to make the income thresholds more realistic, so as to attract not only building owners with the lowest incomes. An increase in the grant itself could be another incentive in this regard. The lack of large numbers of applications appears to confirm these observations. As concerns prospective beneficiaries who possess a high ecological awareness, one element that discourages them from applying to this programme may be the lack of incentives for using zero-emission heating systems. The subsidies for those who replace conventional stoves with zero-emission heating systems, such as thermal pumps, ought to be more attractive than the incentives for those buying coal-fuelled systems. Moreover, financial support for the purchase and installation of solar collectors and photovoltaic modules is offered only in the form of a loan.

The last of the potential limitations identified in an analysis of the Clean Air Programme is its funding. In 2018, this came from National Fund monies, making over PLN 1 billion (PLN 1,004 million) available to the Regional Funds on the basis of bilateral contracts (Narodowy Fundusz Ochrony Środowiska i Gospodarki Wodnej, 2019, pp. 26, 94). Apart from the National Fund's own coffers, the programme is to be realised also from EU funding. According to press reports, in the next fi- 
nancial forecast for the period 2012-2027, Poland should receive up to EUR 8 billion to combat air pollution (Wantuch, 2019b).

The Polish government has subsequently undertaken collaboration under the Clean Air Programme with experts from the EU and the World Bank as part of the European Commission Coordination Team, World Bank and National Fund in home energy efficiency. The Team was established for the purposes of giving recommendations for the form and procedures of programme realisation so as to gain support from EU funds (both those unused under the present financial forecast as well as future funds). The head of the Team - Wolfgang Münch, during his second meeting on 31 August 2018, stated that "[t]he EU intends to support actions with financial aid to improve air quality by Poland" (Eksperci, 2018).

In May 2018, the World Bank, acting on the recommendation of the European Commission, that is prior to the commencement of the Clean Air Programme, presented a report on strategies for public support of thermo-modernisation and replacement of heating appliances and systems in homes in Poland, together with a cost analysis (International Bank for Reconstruction and Development, 2018). The European Commission conditioned the designation of EU funds for combatting smog in Poland on adherence to select World Bank recommendations. Thus far, the National Fund has responded by including municipal offices in programme operations and discontinuing support for investment in newly constructed homes as of 2020. Among the expected changes, the following ought to be mentioned:

- simplification of applications and their processing;

- allowing municipal local governments to assess applications, rather than merely verifying them;

- creation of effective channels for the distribution of funds to beneficiaries by means of cooperation with banks and local governments in the transfer of monies.

The European Commission has also raised doubts over the programme's replacement of inefficient solid fuel heating systems with newgeneration coal-fired boilers. In spite of particular circumstances where such investments are only planned since the connection to a local heating or gas distribution network is neither possible nor cost-effective, the European Commission can demand resignation from coal-fired boilers because the EU aims to completely resign from coal by the end of the 2020s at the earliest. In this context, the European Parliament accepted the Resolution of 13 March 2019 on a Europe that protects: Clean air for 
all (2018/2792(RSP)), calling on member states to resign from coal as a source of energy by 2030 (European Parliament, 2019).

Due to the lack of adherence to these expert opinions, Marc Lemaitre - Director General for Regional and Urban Policy, sent a letter to the Minister for the Environment Henryk Kowalczyk, Minister for Investment and Development Jerzy Kwieciński, Minister for Business and Technology Jadwiga Emilewicz, the Prime Minister's Delegate for the Clean Air Programme Piotr Woźny, as well as to National Fund representatives and the World Bank, stating that "[t]he present programme does not qualify for structural funds [...]. Unfortunately, as of September 2018 when the programme commenced, only 7,500 contracts have been signed [...]. Progress is very slow, resulting from a lack of an appropriate coordinator of actions taken by Poland" (Wantuch, 2019c) -which was revealed by the Gazeta Wyborcza newspaper. In July 2019, Minister Henryk Kowalczyk during his press conference assured that the Ministry for the Environment "is in a constant dialogue with the European Commission and World Bank, and that there are cyclical meetings according to the previously established timetable" (Minister, 2019). So far, up to the end of August 2019, neither the European Commission nor the Ministry for the Environment in Poland has notified the public that a compromise has been achieved - one that would appear to be essential for ensuring funding for this programme.

\section{Conclusion}

The National Fund for Environmental Protection and Water Management's Clean Air Priority Programme is the largest project in terms of duration and budget launched by the government to limit low-level emissions from homes in Poland. This brief study, drawing on the institutional-legal, decision-making and quantitative analysis, has undertaken to answer the following research questions: (1) whether the realisation of the aim formulated in this programme can result in an improvement of air quality in Poland, (2) what, if any, barriers stand in the way of achieving the programme's aims, and (3) whether the Clean Air Programme requires further changes.

On account of the high energy consumption in most Polish homes, which typically results in their owners heating them with the cheapest fuels emitting significant amounts of pollution (especially particulate matter) the programme's aims ought to be positively viewed. The complete realisation 
of programme aimsand the replacement of at least three million old-generation boilers with low-emission ones, the improvement of energy efficiency of over three million homes and, as a consequence, the limitation of $\mathrm{SO}_{2}$, $\mathrm{PM}_{10}, \mathrm{PM}_{2.5}$, benzo- $\alpha$-pyrene and $\mathrm{CO}_{2}$, provides hope for a significant improvement in air quality and limiting low-level emissions.

In the above discussion, however, three types of barriers have come to light: (1) those related to the effective distribution of funds, (2) difficulties arising from the programme frameworks that potential beneficiaries might encounter, and (3) potential limitations in the access to EU funding. The introduction of changes in the Clean Air Programme is essential for achieving the established ecological aims. Subsequent amendments should above all concern:

- allowing municipal local governments to assess applications;

- broadening the effective channels for the distribution of funds to beneficiaries by means of cooperation with banks and local governments in the transfer of monies, not just by means of Regional Environmental Protection and Water Management Funds;

- making financial support available to local governments in the realisation of the tasks set under the programme;

- making income thresholds more realistic, so as to encourage broader participation in the programme, appealing not only to the most impoverished of building owners;

- providing financial support for the purchase and installation of solar collectors and photovoltaic modules, not only in the form of loans but also grants.

\section{Bibliography}

Apel o zmiany w Programie „Czyste Powietrze” (2019), Polski Alarm Smogowy, 14.01.2019, https://polskialarmsmogowy.pl/files/artykuly/1907.pdf, 20.08.2019.

Bank Światowy rekomenduje włączenie banków i gmin do programu Czyste Powietrze, 20.05.2019, https://www.teraz-srodowisko.pl/aktualnosci/wozny-program-czyste-powietrze-banki-gminy-6967.html, 15.08.2019.

Co to sa muly i flotokoncentraty węglowe, Poznań City Portal, http://www.poznan.pl/ mim/main/-,p,43191,43199.html, 6.08.2019.

Commission Regulation (UE) 2015/1189 of 28 April 2015 implementing Directive 2009/125/EC of the European Parliament and of the Council with regard to ecodesign requirements for solid fuel boilers, OJ EU L 193/100, 21.07.2015. 
Eksperci z Komisji Europejskiej i Banku Światowego zapoznali się z programem „CZyste Powietrze", 31.08.2018, http://nfosigw.gov.pl/czyste-powietrze/aktualnosci/art,4,eksperci-z-komisji-europejskiej-i-banku-swiatowego-zapoznali-siez-programem-czyste-powietrze.html, 25.08.2019.

European Parliament resolution of 13 March 2019 on a Europe that protects: Clean air for all, 2018/2792(RSP), http://www.europarl.europa.eu/doceo/document/ TA-8-2019-0186_EN.html, 27.08.2019.

Exposé premiera Mateusza Morawieckiego - stenogram (2017), Warszawa, https:// www.premier.gov.pl/expose-premiera-mateusza-morawieckiego-stenogram. html, 1.08.2019.

Gajewski D., Kulon A. (2011), Finansowanie ochrony środowiska i gospodarki wodnej: [art. 400-421 Prawa ochrony środowiska]: komentarz, C.H. Beck, Warszawa.

Instytut Ochrony Środowiska - Państwowy Instytut Badawczy, Krajowy Ośrodek Bilansowania i Zarządzania Emisjami (2019), Krajowy bilans emisji $\mathrm{SO}_{2}, \mathrm{NO}_{x^{*}}$ $\mathrm{CO}, \mathrm{NH}_{3}, \mathrm{NMLZO}$, pytów, metali ciężkich i TZO za lata 2015-2017 w uktadzie klasyfikacji SNAP. Raport syntetyczny, Warszawa, https://www.kobize.pl/ uploads/materialy/materialy_do_pobrania/krajowa_inwentaryzacja_emisji/ Bilans_emisji_za_2017.pdf, 7.08.2019.

International Bank for Reconstruction and Development (2018), Poland catching-up two regions: fighting smog - energy efficiency and anti-smog in single family buildings in Poland, Washington.

Jakość powietrza to jakość życia. Poradnik antysmogowy (2018), Poznań, https:// www.wfosgw.poznan.pl/wp-content/uploads/2018/04/poradnik-antysmogowy.pdf, 6.08.2019.

Jędrak J., Konduracka E. (2017), Wpływ zanieczyszczeń powietrza na zdrowie, Krakowski Alarm Smogowy, Kraków.

Judgment of the Court of Justice of the European Union, 22 February 2018, Commission v Poland, Failure of a Member State to fulfil obligations - Directive 2008/50/WE - Ambient Air, ECLI:EU:C:2018:94.

Kowalczyk: podpisano 400 porozumień z gminami ws. programu Czyste Powietrze, 31.07.2019, http://samorzad.pap.pl/depesze/wiadomosci_pap/192587/, 20.08.2019.

Leksykon ochrony środowiska (2009), ed. J. Ciechanowicz-McLean, C.H. Beck, Warszawa.

Mazurek H. (2018), Konsekwencje ekspozycji dla uktadu oddechowego u dzieci, in: Smog. Konsekwencje zdrowotne zanieczyszczeń powietrza, PZWL Wydawnictwo Lekarskie, Warszawa.

Minister Kowalczyk o Programie Czyste Powietrze, 2.07.2019, https://www.gov. $\mathrm{pl} / \mathrm{web} /$ srodowisko/minister-kowalczyk-o-programie-czyste-powietrze, 17.08.2019.

Ministerstwo Środowiska - Departament Ochrony Powietrza (2015), Krajowy program ochrony powietrza do roku 2020 (z perspektywa do roku 2030), Warszawa, https://powietrze.gios.gov.pl/pjp/publications/card/3153, 8.08.2019. 
Nabór wniosków w programie Czyste Powietrze wznowiony, 17.01.2019, http://www. nfosigw.gov.pl/o-nfosigw/aktualnosci/art,1359, nabor-wnioskow-w-progra mie-czyste-powietrze-wznowiony.html, 1.08.2019.

Najczęściej zadawane pytania, https://wfos.gdansk.pl/czyste-powietrze/faq-najczesciej-zadawane-pytania, 17.08.2019.

Narodowy Fundusz Ochrony Środowiska i Gospodarki Wodnej (2019a), Sprawozdanie z działalności Narodowego Funduszu Ochrony Środowiska i Gospodarki Wodnej w 2018 roku, Warszawa, https://nfosigw.gov.pl/gfx/nfosigw/userfiles/ files/o_nfosigw/sprawozdania_z_dzialalnosci/2019/sprawozdanie_z_dzialalnosci_nfosigw_w_2018_r..pdf, 1.08.2019.

Narodowy Fundusz Ochrony Środowiska i Gospodarki Wodnej (2019b), Regulamin naboru wniosków o dofinansowanie przedsięwzięć w ramach Programu Priorytetowego Czyste Powietrze, Warszawa, https://portalbeneficjenta.wfosgw. poznan.pl/data/uploads/Regulamin\%20naboru\%20wniosków\%20obowiązujący\%20od\%20dn\%2029\%2007\%202019r\%20.pdf, 19.08.2019.

Narodowy Fundusz Ochrony Środowiska i Gospodarki Wodnej (2016a), Wspólna Strategia Działania Narodowego Funduszu i wojewódzkich funduszy ochrony środowiska i gospodarki wodnej na lata 2017-2020, Warszawa, https://nfosigw.gov.pl/o-nfosigw/strategia/, 1.08.2019.

Narodowy Fundusz Ochrony Środowiska i Gospodarki Wodnej (2016b), Sprawozdanie z działalności Narodowego Funduszu Ochrony Środowiska i Gospodarki Wodnej w 2015 roku, Warszawa, https://nfosigw.gov.pl/gfx/nfosigw/userfiles/ files/life/sprawozdania/sprawozdanie_z_dzialalnosci_nfosigw_w_2015_r. pdf, 2.08.2019.

Narodowy Fundusz Ochrony Środowiska i Gospodarki Wodnej (2014), Narodowy Fundusz Ochrony Środowiska i Gospodarki Wodnej 1989-2014. Odnawialne źródto ekorozwoju. Zmieniliśmy i zmieniamy Polskę, Warszawa.

Nocuń K. (2019), „Czyste powietrze” wyladowało na barkach samorzadów, 28.07.2019, “Gazeta Prawna”, https://serwisy.gazetaprawna.pl/ekologia/artykuly/1423878, wymiana-kotlow-i-piecow-czyste-powietrze.html, 20.08.2019.

Nowy program zamiast KAWKI - trwają konsultacje, https://nfosigw.gov.pl/oferta-finansowania/srodki-krajowe/programy-priorytetowe/poprawa-jakosci-powietrza/ aktualnosci/, 2.08.2019.

Ogłoszenie o zmianie Programu Priorytetowego Czyste Powietrze, 23.07.2019, http:// www.wfosgw.poznan.pl/ogloszenie-o-zmianie-programu-priorytetowegoczyste-powietrze/, 1.08.2019.

Pałasz J. (2016), Niska emisja ze spalania węgla i metody jej ograniczenia, Wydawnictwo Politechniki Śląskiej, Gliwice.

Program „Czyste powietrze”: Na jesieni zmiany w termomodernizacji budynków, 31.07.2018, https://www.portalsamorzadowy.pl/gospodarka-komunalna/program-czyste-powietrze-na-jesieni-zmiany-w-termomodernizacji-budynkow, 111280.html, 19.08.2019. 
Program Priorytetowy Czyste Powietrze (2019), 1.6 version as of 29.07.2019, http:// www.wfosgw.poznan.pl/program-priorytetowy-czyste-powietrze/program-priorytetowy-czyste-powietrze-zasady-obowiazujace-od-29-07-2019-r/, 1.08.2019.

Program Priorytetowy Czyste Powietrze (2018), 1.4 version as of 19.09.2018, http:// www.wfosgw.poznan.pl/program-priorytetowy-czyste-powietrze/program-priorytetowy-czyste-powietrze-wersja-obowiazujaca-do-31-12-2018-r/, 12.08.2019.

Program Priorytetowy Likwidacja niskiej emisji wspierajaca wzrost efektywności energetycznej i rozwój rozproszonych odnawialnych źródet energii, część 1: Program pilotażowy KAWKA, https://www.wfosigw.zgora.pl/artykul/programy/program-kawka, 2.08.2019.

Program Priorytetowy Poprawa efektywności energetycznej, część 4: Ryś - termomodernizacja budynków jednorodzinnych (2015), https://www.nfosigw.gov.pl/ oferta-finansowania/srodki-krajowe/programy-priorytetowe/rys---termomodernizacja-budynko-jednorodzinnych/informacje-o-programie/, 2.08.2019.

Program Priorytetowy Prosument - linia dofinansowania z przeznaczeniem na zakup i montaż mikroinstalacji odnawialnych źródeł energii, dokument do pobrania na stronie NFOŚiGW, https://www.nfosigw.gov.pl/oferta-finansowania/srodki-krajowe/programy-priorytetowe/prosument-dofinansowanie-mikroinstalacji-oze/informacje-o-programie/, 2.08.2019.

Pytliński Ł. (2018), Stan techniczny budynków jednorodzinnych w Polsce. Potrzeby remontowe, źródła ogrzewania i standardy izolacyjności cieplnej. Raport z badań, in: Efektywność energetyczna w Polsce. Przeglad 2017. Domy jednorodzinne. Smog, eds. E. Walczak, M. Zaborowski, Instytut Ekonomii Środowiska, Kraków.

Pytliński Ł. (2014), Węgiel, stare piece i brak ocieplenia. Systemy grzewcze i izolacja termiczna $w$ sektorze domów jednorodzinnych $w$ Polsce. Raport z badań, in: Domy jednorodzinne: efektywność energetyczna a jakość powietrza, Instytut Ekonomii Środowiska, Kraków.

Rekomendacje Komitetu Ekonomicznego Rady Ministrów w sprawie dziatań niezbędnych do podjęcia w zwiazku z występowaniem na znacznym obszarze kraju wysokiego stężenia zanieczyszczeń powietrza, 17.01.2017, https://www.premier. gov.pl/wydarzenia/decyzje-rzadu/rekomendacje-komitetu-ekonomicznegorady-ministrow-w-sprawie-dzialan.html, 1.08.2019.

Sakson-Boulet A. (2018), The State of Air in the European Union and Quality of Europeans' Life, "Przegląd Politologiczny", no. 4, https://doi.org/10.14746/ pp.2018.23.4.9.

Ustawa o zmianie ustawy o podatku dochodowym od osób fizycznych oraz ustawy o zryczaltowanym podatku dochodowym od niektórych przychodów osiaganych przez osoby fizyczne z dnia 9 listopada 2018 r., Dz. U. 2018, poz. 2246.

Ustawa Prawo ochrony środowiska z dnia 27 kwietnia 2001 r., Dz. U. 2001, Nr 62, poz. 627. 
Walczak E., Zaborowski M. (2018)., Krajowy program modernizacji budynków, in: Efektywność energetyczna w Polsce. Przeglad 2017. Domy jednorodzinne. Smog, eds. E. Walczak, M. Zaborowski, Instytut Ekonomii Środowiska, Kraków.

Wantuch D. (2019a), Komisja Europejska straciła cierpliwość. Polska bez kasy na smog, "Gazeta Wyborcza", 19.06.2019.

Wantuch D. (2019b), Miliardy na smog. Jeśli naprawdę zaczniemy z nim walczyć, "Gazeta Wyborcza", 20.03.2019.

Wantuch D. (2019c), Popłoch w PiS po liście Komisji Europejskiej, "Gazeta Wyborcza", 26.06.2019.

Wantuch D. (2016), Koniec dotacji na wymianę pieców i ocieplanie domów. Rząd stawia na wegiel, nie na czyste powietrze, "Gazeta Wyborcza", 18.03.2016.

Woźny zapowiada uszczelnienie przepisów ws. jakości kotłów, 22.03.2018, https:// www.teraz-srodowisko.pl/aktualnosci/wozny-zapowiada-uszczelnienieprzepisow-ws-jakosci-kotlow-4422.html, 14.08.2019.

Zaborowski M. (2014), Finansowanie remontów i termomodernizacji (zwiększenia efektywności energetycznej) w budynkach jednorodzinnych, in: Strategia modernizacji budynków: mapa drogowa 2050, Buildings Performance Institute Europe, Instytut Ekonomii Środowiska, Narodowa Agencja Poszanowania Energii, Krajowa Agencja Poszanowania Energii, Kraków.

\section{Program priorytetowy „Czyste Powietrze” - ocena i perspektywy}

\section{Streszczenie}

Celem artykułu jest ocena efektywności programu priorytetowego „Czyste Powietrze" oraz określenie ewentualnych zagrożeń dla jego powodzenia. Program Narodowego Funduszu Ochrony Środowiska i Gospodarki Wodnej stanowi istotny element rządowego programu o tej samej nazwie. W artykule, przy zastosowaniu analizy instytucjonalno-prawnej, decyzyjnej i ilościowej, podjęto próbę odpowiedzi na następujące pytania badawcze: 1) czy realizacja sformułowanego w programie celu może przełożyć się na poprawę jakości powietrza w Polsce?; 2) czy i jakie bariery stoją na drodze do osiągnięcia celu programu?; 3) czy program „Czyste Powietrze” wymaga kolejnych korekt? W związku z wysoką energochłonnością jednorodzinnych budynków mieszkalnych w Polsce, która zazwyczaj prowadzi do wykorzystania przez ich właścicieli najtańszych i emitujących dużo zanieczyszczeń paliw do ogrzewania, cele programu należy ocenić pozytywnie. W toku przeprowadzonych rozważań wykazano jednak, że ich realizacja ograniczona jest trzema rodzajami barier: 1) związanymi ze sprawną dystrybucją środków; 2) trudnościami dla potencjalnych beneficjentów wynikających z konstrukcji programu; 3) potencjalnymi ograniczeniami w dostępie do finansowania ze środków unijnych. W związku ze zidentyfikowaniem zagrożeń dla powodzenia 
programu, należy oczekiwać wprowadzenia dalszych zmian jego funkcjonowania oraz zabezpieczenia środków na finansowanie termomodernizacji i wymiany źródeł ogrzewania.

Słowa kluczowe: jakość powietrza, smog, polityka ochrony powietrza, program „Czyste Powietrze”, Polska 